\title{
Air sacs (sacci pneumatici) in the long-legged buzzard (Buteo rufinus)
}

\author{
İsmail Önder ORHAN ${ }^{1}$, Murat KABAK ${ }^{2}$, Çağdaş OTO ${ }^{1}$, Reşide Merih HAZIROĞLU ${ }^{1}$ \\ ${ }^{1}$ Ankara University, Faculty of Veterinary Medicine, Department of Anatomy, Ankara; ${ }^{2}$ Onkoduz Mayıs University, Faculty of \\ Veterinary Medicine, Department of Anatomy, Samsun, Turkey.
}

\begin{abstract}
Summary: Although, a lot of researchers have investigated air sacs in several birds' species, there hasn't been any information about the long-legged buzzard's air sacs. This study aimed to observe the air sacs of mature long-legged buzzard. So the sacs of 5 adult birds were treated by takilon from methylmethacrylate group and colored-neoprene latex for polymerization in order to show and demonstrate the total volume of air sacs and invaded bone tissues. The morphology of the sacs, which was described, was similar to that of other bird species. Significant characteristics such as an additional cardiac diverticulum of the cranial thoracic sac and diverticulum interpulmonalis of saccus cervicalis were demonstrated. We also showed that first four vertebras were not pneumatized in long legged buzzard.

Key words: Air sac, anatomy, long-legged buzzard, respiratory system.
\end{abstract}

\section{Kızıl şahinde (Buteo rufinus) hava keseleri (sacci pneumatici)}

Özet: Çok sayıda araştırmacı, birçok kuş türünde hava keselerini incelemiş olmasına rağmen, kızıl şahinin hava keseleri hakkında herhangi bir bilgiye ulaşılamamıştır. Bu çalışma ile yetişkin kızıl şahinde hava keselerinin ayrıntılı olarak tanımlanması amaçlanmıştır. Araştırmada, hava keselerinin toplam hacmini ve kemik doku ile ilişkisini göstermek amacıyla 5 adet ergin kızıl şahinin hava keseleri metilmetakrilat grubundan takilon ve polimerizasyon için renklendirilmiş lateks ile doldurulmuştur. Keselerin morfolojisinin diğer kuş türleri ile benzer olduğu belirlenmiştir. Saccus thoracicus cranialis'in diverticulum cardiale'si ve saccus cervicalis'in diverticulum interpulmonalis'i gibi belirgin özellikler demonstre edilmiştir. Ayrıca kızıl şahinde ilk dört omurun pnömatize olmadığı görülmüştür.

Anahtar sözcükler: Anatomi, hava keseleri, kızıl şahin, solunum sistemi.

\section{Introduction}

The respiratory organs of birds differ from mammals in a number of specific features, mostly associated of requirements of flight and voice production. The lungs are small and very vascular, and expand very little, whereas their accessory organs, the thin-walled air sacs, are responsible for pulmonary ventilation on both inspiration and expiration. However, gas exchange does not occur in the air sacs, but instead occurs in the air capillaries, which are branches of the parabronchi in the lungs. Air sacs pass among the viscera and even extend into many of the bones $(8,9)$.

Morphology of the air sacs in several avian species has been well documented $(1,3,4,11,13,17)$. But the studies which were observed on the air sacs of wild birds are limited (15).

The long-legged buzzard is a widespread breeding bird in Turkey, but it can also be found in Balkans, Eastern Europe, the mountainous region of the Caucasus and even Middle East. This wide geographic area also has migratory routes for many species of birds that fly very long distances. Migratory species have difficulties at crossing points where they were hunted by long-legged buzzard during their journey. This also means that massive numbers of large raptors, including long-legged buzzard, are exposed to the infections that is carried by these birds at migration times (10).

Avian influenza virus spreads in the air and it can also be transmitted by contaminated feed and water (5). Recently the avian influenza virus has been confirmed in humans, ordered by the number of known human deaths, in Turkey (20). The long-legged buzzard might have a role in order to distribute of this virus as well as other bird species and can be responsible avian flu in this region. We believe that this study that reveals the anatomy of respiratory system of long-legged buzzard will be helpful to the investigators on this matter.

This observation aimed at revealing the features of the air sacs, documenting the differences if there are, and further expanding our knowledge with contribution to the literature.

\section{Materials and Methods}

Five adult long-legged buzzards (Buteo rufinus) were used in this study. The birds were referred to surgery clinics of veterinary faculty for the treatment of their wings injuries but they couldn't be survived. 
The birds were deeply anesthetized by intramuscular administration of diazepam $(1 \mathrm{mg} / \mathrm{kg})$ and ketamine HCI (30 mg/kg) combination (19).

In order to show and demonstrate the total volume of air sacs, and invaded bone tissues liquid and powder mixture (Takilon ${ }^{\circledR}-$ Varpa Ltd Co) from methylmethacrylate group was given into two of the birds. Two hours after takilon injection, all the materials, including bone tissues, were kept into $\% 3 \mathrm{KOH}$ at $40{ }^{\circ} \mathrm{C}$ until all body tissues macerated and solution were kept changed frequently in order to keep solution clean. Finally, the takilon cast that took on the shapes of air sacks was rinsed under running tap water and examined.

Last three buzzards were injected via trachea by colored-neoprene latex (ZPK-582-G, Educational \& Scientific Products Ltd, Rustington, UK). The materials were left to decay of the soft tissues for two months. Finally, corroded soft tissues were removed and rinsed with tap water (18). Nomina Anatomica Avium (2) was used for the nomenclature.

\section{Results}

Four paired air sacs and one unpaired sac located deep in the body cavity and these sacs relation to the lungs (Figures 1/A, 2/A, 4/1) were revealed. These sacs had variously shaped diverticula, which were into the pneumatic bones of the skeleton of the trunk and the pectoral and pelvic girdles.

The unpaired, bilaterally symmetrical clavicular sacs (saccus clavicularis) (Figures 1/C, 2/C, 3/A) were ventrally fused. The others were named cervical sac (saccus cervicalis), (Figures 1/B, 2/B) cranial thoracic sac (saccus thoracicus cranialis) (Figures 1/D, 3/B), caudal thoracic sac (saccus thoracicus caudalis) (Figures 1/E, 2/D, 3/C), and abdominal sac (saccus abdominalis) (Figures 1/F, 2/E, 3/D). The air sacs invaded the skeleton through either a large pneumatic foramen or small pneumatic pores.

The cervical sac: The cervical sac (Figures 1/B, 2/B) was bilaterally located at ventral of the last two cervical and first thoracic vertebras, in between dorsal half of margo cranialis of lungs and clavicular sac. It consisted of a pair of main chambers and diverticula. The main chambers combined to form a median compartment. Saccus cervicalis was wider at caudal and it became narrower as it elongated to cranial. It was communicated with lungs via the first medioventral bronchus.

The extended part of saccus cervicalis to cranial direction is vertebral diverticulum (diverticula vertebralia) (Figures 1/1, 2/1, 3/1). It has a pair of tubular extensions that took place at both sides of columna vertebralis and passed through foramina transversaria up to fourth cervical vertebra. Also, vertebral diverticulum has an extention that runs inside of canalis vertebralis until the fourth cervical vertebra. These intra and extra extentions of vertebral diverticulum are connected with each other and run inside of foramina intervertebralia. It was noted that vertebral diverticulum aerated all cervical vertebras with an exception of the first four cervical vertebras.

The other diverticulum was placed intermuscular, intermuscular diverticula (diverticula intermuscularia) (Figures 1/2, 2/2) was located dorsolateral to the subscapular diverticulum of the clavicular sacs, which was $1-2 \mathrm{~cm}$ in length.

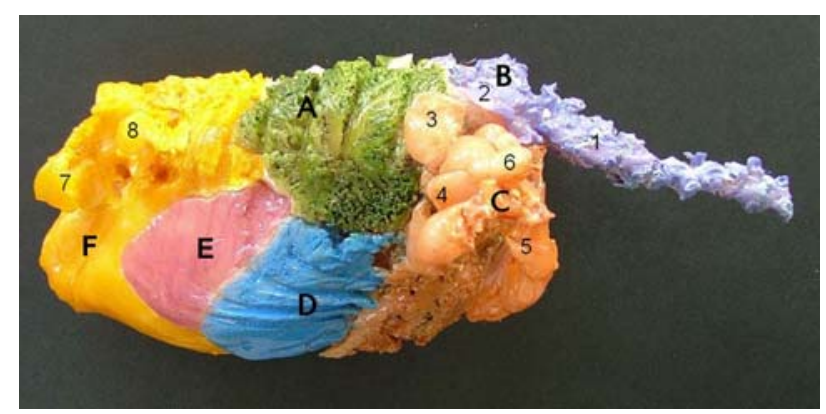

Figure 1. Right view of the air sacs of the long-legged falcon. A- lungs, B- cervical sac, C- clavicular sac, D- cranial thoracic sac, E- caudal thoracic sac, F- abdominal sac, 1- vertebral diverticulum, 2- intermuscular diverticulum, 3- subscapular diverticulum, 4- axillar diverticulum, 5- subpectoral diverticulum, 6- suprahumeral diverticulum, 7- femoral diverticulum, 8- perirenal diverticulum

Şekil 1. Kızıl Şahin'de hava keselerinin sağ yandan görünümü. A- akciğerler, B- saccus cervicalis, C- saccus clavicularis, D- saccus thoracicus cranialis, E- saccus thoracicus caudalis, F- saccus abdominalis, 1- diverticula vertebralia, 2- diverticula intermuscularia, 3- diverticula subscapularea, 4- diverticula axillaria, 5- diverticula subpectoralia, 6- diverticula suprahumeralia, 7- diverticula femoralia, 8- diverticula perirenalia.

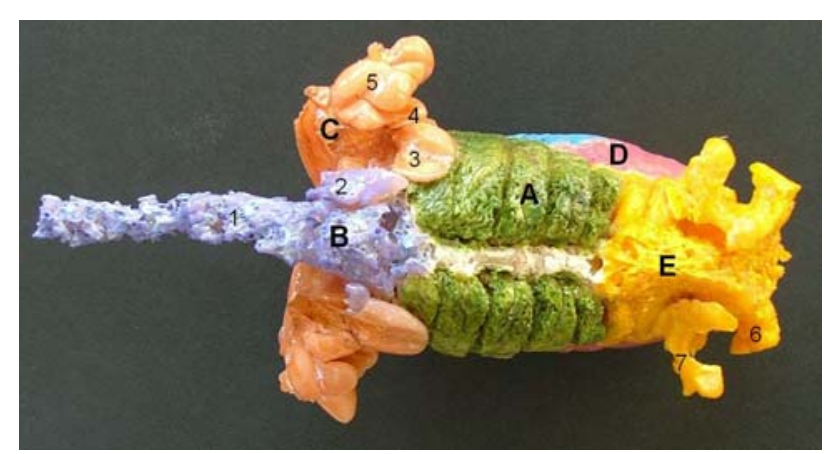

Figure 2. Dorsal view of the air sacs of the long-legged falcon. A- lungs, B- cervical sac, C- clavicular sac, D- caudal thoracic sac, E- abdominal sac, 1- vertebral diverticulum, 2intermuscular diverticulum, 3- subscapular diverticulum, 4axillar diverticulum, 5- suprahumeral diverticulum, 6- femoral diverticulum, 7- perirenal diverticulum.

Şekil 2. Kızıl Şahin'de hava keselerinin dorsal'den görünümü. A- akciğerler, B- saccus cervicalis, C- saccus clavicularis, Dsaccus thoracicus caudalis, E- saccus abdominalis, 1- diverticula vertebralia, 2- diverticula intermuscularia, 3- diverticula subscapularia, 4- diverticula axillaria, 5- diverticula suprahumeralia, 6- diverticula femoralia, 7- diverticula perirenalia. 




Figure 3. Ventral view of the air sacs of the long-legged falcon. A- clavicular sac, B- cranial thoracic sac, C- caudal thoracic sac, D- abdominal sac, 1- vertebral diverticulum, 2- axillar diverticulum, 3- subpectoral diverticulum, 4- sternal diverticulum, 5- cardial diverticulum, 6- subcardial diverticulum.

Şekil 3. Kızıl Şahin'de hava keselerinin ventral'den görünümü. A- saccus clavicularis, B- saccus thoracicus cranialis, C- saccus thoracicus caudalis, D- saccus abdominalis, 1- diverticula vertebralia, 2- diverticula axillaria, 3- diverticula subpectoralia, 4- diverticulum sternale, 5- diverticulum cardiale, 6- diverticulum subcardiale.

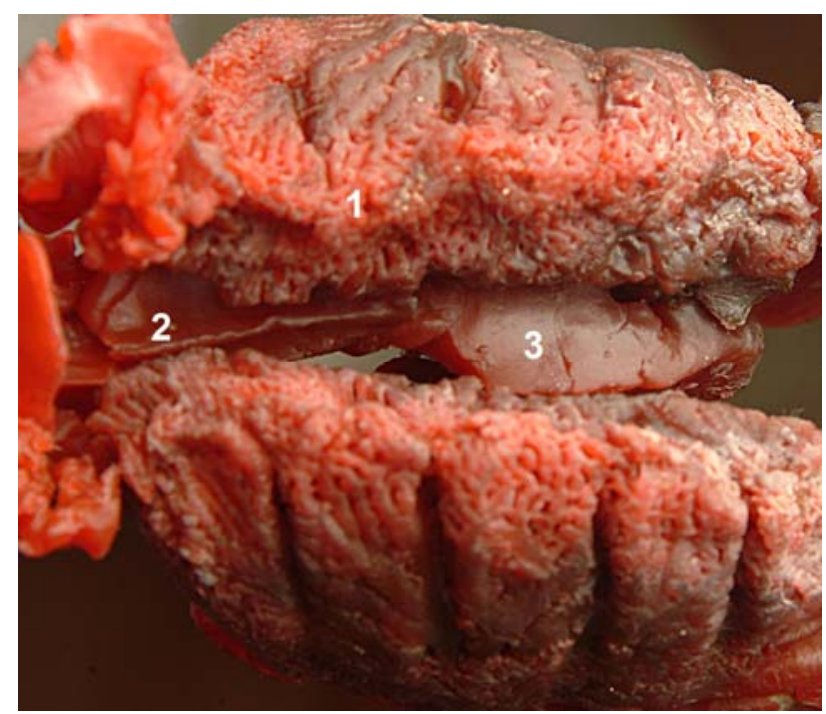

Figure 4. Dorsal view of the air sacs of the long-legged falcon (colored with latex).

1- lungs, 2- interpulmonal diverticulum, 3- supracardial diverticulum.

Şekil 4. Kızıl Şahin'de hava keselerinin dorsal'den görünümü (lateks ile renklendirilmiş).

1- akciğerler, 2- diverticulum interpulmonale, 3- diverticulum supracardiale.

There was another unpaired median diverticulum, which was lying cranioventrally between the two lungs, interpulmonal diverticulum (diverticulum interpulmonale) (Figure 4/2). When we compared this diverticulum with others, it had the smallest size volume.

The clavicular sac: The clavicular sac (Figures 1/C, 2/C, 3/A) was a big chamber, consisted of ventral fusion of lateral and medial sacs in the middle, which was beneath the trachea and shoulder where the wings attached to the body. The sac was surrounded entirely by the pectoral girdle, the sternum and completely occupied the cranial thoracic aperture.

The clavicular sac was being separated from the cervical sac by help of trachea and esophagus. It was connected to the lungs via the first and second medioventral bronchi. The clavicular sac had several diverticula, which were divided into intrathoracal and extrathoracal.

Intrathoracal diverticula (diverticula intrathoracica) were located at the entry of thorax, close to the base of sternum and at the cranial part of heart and lungs. Sternal diverticulum (diverticulum sternale) (Figure 3/4) was intrathoracal, which lied dorsal to the sternum, aerating the sternum.

Extrathoracal part took place around bones and muscles that consisted of shoulder band. First extrathoracal diverticula (diverticula extrathoracica) were the subscapular diverticula (diverticula subscapularea) (Figures 1/3, 2/3), which were leaf-like structures located in between the scapula and cervical sac. Lateral to those was present the axillar diverticula (diverticula axillaria) (Figures 1/4, 2/4, 3/2), which gave branches off small diverticula that aired os coracoids. Another extrathoracally located diverticula was the subpectoral diverticula (diverticula subpectoralia) (Figures 1/5, 3/3) which was ventral to the axillar diverticulum, lateral to the first two ribs, and under the pectoral muscles. The last extrathoracally located one, suprahumeralia diverticula (diverticula suprahumeralia) (Figures 1/6, 2/5) was dorsal to the subpectoral diverticula, entered humerus from proximal and aired the bone all the way to the end. It was noticed that proximal of this diverticula was the most developed part.

The cranial thoracic sac: It was a pair of intrathoracic located sac which looked like a symmetrical rectangular from lateral. It extended to sternal ribs at lateral, to the lungs from ventromedial. It was ventilated through bronchi medioventrales. Heart, liver and the caudal portion of the esophagus and proventriculus assembled the medial side of this sac.

It was noted that there was a diverticulum attached to the medial side of the cranial thoracic sac (Figures 1/D, 3/B) from left end. Cardial diverticulum (Diverticulum cardiale) (Figure 3/5) located at cranioventral of the heart and enclosed the ventral part of the heart. Subcardial diverticulum (Diverticulum subcardiale) (Figure 3/6) surrounded the heart from lateral sides as two small diverticula.

An additional diverticulum was demonstrated at the medial side of the cranial thoracic sac from right end, supracardial diverticulum (diverticulum supracardiale) (Figure 4/3) was at dorsal side of the heart, lying between heart and lungs. Supracardial diverticulum extended up 
to caudal end of interpulmonal diverticulum, which belonged to the clavicular sac at cranial.

Cranial thoracic sac ventilated sternal ribs with an exception of last two ribs. It aired sternum where it touched at medial side and ventilated sternal ribs close to sternocostal articulations.

There were extrathoracal diverticula in between the first five ribs and sternum. These intercostal diverticula passed through intercostal spaces at the level of sternocostale articulations and lasted with an extension at the lateral side of the ribs.

The caudal thoracic sac: The caudal thoracic sac (Figures 1/E, 2/D, 3/C) consisted of paired, flat, asymmetrical air sacs. A group of parabronchi and bronchi lateroventralis, located caudoventral of the lungs, aired this sac. In spite of the large size of the cranial thoracic sac, the caudal thoracic sac was quite small. The caudal thoracic sac did not have any diverticulum. Because of the abdominal sac and the cranial thoracic sac at medial side, it was hardly in contact with internal organs. Lateral side of the sac reached last two vertebral ribs craniodorsally and it did not pneumatize any bone tissue that surrounded.

The abdominal sac: It was the largest sac. The abdominal sac (Figures 1/F, 2/E, 3/D) occupying most of the peritoneal cavity, took place asymmetrically as two parts in the abdomen. It extended from ostium caudale, which is the continuation of bronchus primaries, through pelvic cavity. This sac was connected with the lungs through lateroventral bronchi. The asymmetrical left abdominal sac was larger than the right one and its starting and ending points were higher at cranial level than the right side.

Right and left abdominal sacs gave off branches to the diverticula that pneumatized synsacrum, ilium, canalis synsacri, seventh thoracic vertebra and ribs. Inner side of the sac was comprised of traces of intestines, and ovarium in female or testis in male. The caudal portion of the sac was narrower.

Femoral diverticula (Diverticula femoralia) (Figures 1/7, 2/6) that located behind the hip joint (articulatio coxae) were very distinctive. Perirenal diverticulum (Diverticula perirenalia) (Figures 1/8, 2/7) mainly enclosed the head of the femur (caput ossis femoris). It also provided air to femur and synsacrum. Perirenal diverticulum entered femur from a large pneumatic foramen that has been ventral to trochanter femoris at the level of obturatorial impress.

In general the cervical sac aerated the vertebral ribs, cervical and thoracic vertebra; the clavicular sac aerated the sternum, thoracic girdle, and wing bones; the cranial thoracic sac aerated sternum, sternal ribs, and intercostal spaces and the abdominal sac aerated the pelvis, synsacrum and femur. The caudal thoracic sac ventilated no bones.

This study revealed the detailed features of the air sacs in the long-legged buzzard.

\section{Discussions and Conclusions}

The anatomical components of the cervical sac reported in other avian species $(4,13,15,18)$ were mostly observed in this study. Although Kürtül et al. (12) demonstrated a prominent diverticulum, interpulmonal diverticulum of cervical sacs, lying in between the two lungs in the rock partridge, Nomina Anatomica Avium (2) did not mention about this diverticulum. In our study, we supported this data by demonstrating interpulmonal diverticulum of cervical sac in the long-legged buzzard. In this study, an additional cardial diverticulum, which was branched off by the left saccus thoracicus cranialis, was seen. Cardial diverticulum was present beneath the heart. While it was constructed by clavicular sac in duck and albatross $(4,15)$. Cardial diverticulum was a part of the cranial thoracic sac in the long- legged buzzard.

Nickel et al. (16) noted that diverticula of cervical sacs pneumatized all the cervical vertebras in the domestic fowl; Also Murray et al. (15) described that the vertebrae are pneumatized as far anteriorly as the axis and as far posteriorly as the last sacral vertebra. The atlas, the coccygeal vertebrae and pygostyle were not pneumatic in the Laysan albatross (Diomedea immutabilis); Getty (7) and Taşbaş et al. (18) stated that first two cervical vertebras were not aerated. In our study we showed that first four vertebras were not pneumatized in long legged buzzard.

Getty (7), Mannega et al. (14) and Taşbaş et al. (18) did not mention any diverticula of the cranial thoracic sac in domestic birds and also Çevik Demirkan et al. (4) stated that the cranial thoracic sac did not aerated any of the bones in the respiratory system in mallard ducks. However, we demonstrated the diverticula of the cranial thoracic sac and those diverticula aerated sternal ribs with an exception last two ribs.

Ellenberger et al. (6) and Nickel et al. (16) showed that the volume of the abdominal sac is larger at the right in the domestic fowl; Murray et al. (15) and Taşbaş et al. (18) showed the left is having a greater volume than the right side in Laysan albatross and Denizli rooster. Our result is parallel to Murray et al. (15) and Taşbaş et al. (18) in the long-legged buzzard.

Previously it was shown by some studies $(13,18)$ that the cranial thoracic sac is larger than the caudal in domestic birds. The others (1) indicated the opposite results. The results of this study indicated that the cranial thoracic sac is larger in size in the long-legged buzzard. 
In conclusion, gross morphology of the air sacs in the long-legged buzzard was closely examined and similarities and differences with the literature were documented.

\section{References}

1. Akester AR (1960): The comparative anatomy of the respiratory pathways in the domestic fowl (Gallus domesticus), pigeon (Colomba livia) and domestic duck (Anas platyrhyncha). J Anat, 94, 487-505.

2. Baumel JJ, King SA, Breasile JE, Evans HE, Berge JCV (1993): Nomina Anatomica Avium, $2^{\text {nd }}$. ed., Prepared by the International Committee on Avian Anatomical Nomenclature, A Committee of The World Association of Veterinary Anatomists. Published by The Nuttall Ornithological Club, Cambridge, Massachusetts.

3. Çalışlar T (1984): Anatomy of Domestic Animals, II. Horse and Poultry Dissection. Istanbul University, Faculty of Veterinary Medicine Press, Istanbul.

4. Çevik Demirkan A, Hazıroğlu RM, Kürtül İ (2006): Air sacs (sacci pneumatici) in mallard ducks (Anas platyrhynchos). Ankara Univ Vet Fak Derg, 53, 75-78.

5. De Jong MD, Hien TT (2006): Avian influenza A (H5N1). J Clin Virology. $35,2-13$

6. Ellenberger W, Baum H (1974): Handbuch Der Verleichenden Anatomie Der Haustiere. Reprint 18, Springer-Verlag, Berlin.

7. Getty R (1975): Sisson and Grossman's The Anatomy of The Domestic Animals. In: King AS, Respiratory system, 5th ed., W.B. Saunders Company, Philadelphia.

8. Hogg DA (1984): The distribution of pneumatisation in the skeleton of the adult domestic fowl. J Anat, 138, 617-629.

9. Hogg DA (1990): The development of pneumatisation in the skull of the domestic fowl. J Anat, 169, 139-151.

10. Horowitz I, Lublin A, Mechani S, Banet-Noach C, Green M, Sobel A (2006): Migratory raptors as disease vectors
Connection address and date:

http://www.raptorsinternational.de/LAST_CONFERENCE /Abstracts/General_Raptor_Studies/hauptteil_general_rapt or_studies.html, $27^{\text {th }}$ February, 2006

11. King AS, McLelland J (1984): Birds, Their Structure and Function. $2^{\text {nd }}$ ed., Bailliere Tindall, London.

12. Kürtül I, Aslan K, Aksoy G, Özcan S (2004): Morphology of the air sacs (Sacci pneumatici) in the rock partridge (Alectoris graeca), Vet Res Com, 28, 553-559.

13. Lucas AH, Keeran RJ, Coussens C (1959): Air sacs of chicken, turkey, duck and owl. Anat Rec, 133, 452-453.

14. Mannega A, Calhoun ML (1968): Morphology of the lower respiratory structures of the white Pekin duck. Poult Sci, 47, 266-280.

15. Murray PH, Fisher HI (1967): Air sacs of respiratory origin in some procellariiform birds. The Condor, 69, 586595

16. Nickel R, Schummer A, Seiferle E (1977): Anatomy of The Domestic Birds. Verlag Paul Parey, Berlin.

17. Taylor RO, Bcone MA, Barnett DD (1962): Plastic infusion and casting of the avian air sacs. Poul Sci, 41, 1940-1943.

18. Taşbaş M, Hazıroğlu RM, Çakır A, Özer M (1994): Morphology of the respiratoric system in Denizli cocks. Ankara Üniv Vet Fak Derg, 41, 154-168.

19. Thurman JC, Tranquilli WJ, BensonGJ (1996): Lumb $\&$ Jones Veterinary Anesthesia, $3^{\text {th }}$ ed., Lea Febiger, London.

20. World Health Organization (2006): Avian influenza situation in Turkey- update 6 Connection address and date: http://www.who.int/csr/don/2006_01_18/en.html., $\quad 27^{\text {th }}$ February, 2006

Geliş tarihi: 29.04.2008 / Kabul tarihi: 18.06.2008

Adress for correspondence :

Dr. Çăgdaş Oto

Ankara University, Faculty of Veterinary Medicine,

Department of Anatomy, 06110 - Ankara

e-mail : cagdasoto@gmail.com 
